576. 8. 077. $31: 612.822 .1$

慢性脳局所アナフィラキシー家兔脳艏のヒョリンエス

テラーゼ活性值, 遊離ア之, 窒素及び神経 細胞内ケトエノール顆粒に関する研究

第 2 編

慢性脳局所アナフィラキシー家鬼脳㵦の遊離アミノ窒素に関する研究

（本研究は文部省科学研究㹕の補助洰よる）

（本論文要旨は第53回日本精神神経学会並びそ第63回岡山医学総会に発翌）

、岡山大学医学部第一（陣内）外科数室（指導：陣内敎授）

副手畠山哲朗

〔图和 31 年 3 月 3 日受稿〕

\begin{abstract}
第 1 章 緒言並飞文献
第 2 章 実験材料並飞実験方法

第 1 節 実験動物

第 2 節 抽出液作製法

第 3 節 遊離アミノ窒素定量法

第 3 章 実䮖成績

第 1 節 正常家鬼群
\end{abstract}

目

\section{第1章 腥言並に文献}

私は前編飞扔いて牛脳灰白質ホスファチッ ド加牛血清（以下牛脳灰「木」加牛血清々略 記する) の 4 倍稀釈液を静脈内飞注入する方 法と, $\boldsymbol{\alpha}$ 型連鎖状球菌（以下 $\boldsymbol{\alpha}$ 連菌と略記す る）を副鼻腔内に注大する方法とをるちいて， 2 種の慢性脳局所アナフィラキンー家兔（以 下慢性脳局「ア」家鬼と略記する）を生成し， 各々皮質運動領，アンモン角，レンズ核の $\mathrm{ChE}$ 活性值が正常群化比して増加して招り， これは痙攣準備状態が附与されたためである らと推論した。

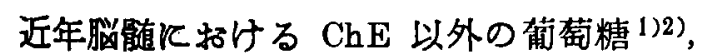
乳酸，アミノ酸，リポイド3，無機物質及び その他の還元物質に関しても生化学的研究が 著々と成果をあげつ〉ある。ことに脳䯣アミ ノ酸代謝は, 脳飞抢ける神経組織の代謝機能
次

第 2 節 牛脳灰白質ホスファチッド加牛 血清群

第 3 節 $\alpha$ 型連鎖状球菌群

第 4 節 小 括

第 4 章 総括並飞洘按

第 5 章 結 論

及び痤攣機序と密接な関係があるとされ，最 近とみに注目をあびている。しかし実際に括 いて脳髄の遊離アミノ酸に関する業績は比輍 的少いようである。まず清水教授》)は大量の 牛脳をるちい, 脳䯣内のクルタミン酸（以下 「ク」酸と略記する)，アラニン、ワリン，ヒ スチヂン，ロインン，チロシン，アルギニン 等を分離定量した. Krebs ${ }^{5)}$, Weil-Malherbe ${ }^{6}$ ), van Slyke, Hamilton ${ }^{7}$ 等は脳龍道全遊離 $ア$ ミ ノ荎素量の 25〜80\%は「ク」酸であるとい つている。また脳髄内に括ける「ク」酸の特 異的な作用機序からも，遊離アミノ酸の変動 は主として「ク」酸を中心とした変動と考え られるのである。すなわちこの脳内「ク」酸 の脳新陳代謝について Weil-Malherbe ${ }^{8)}$ が詳 細な実験を行い,「ク」酸代謝は神経機能にエ ネルギーを供給する代謝であるとしたが，の ちに「ク」酸の酸化的脱アミノ反応は直接に 
エネルギー源とはなりえないるのであり，神 経機能と関連して作用する特殊な代謝である

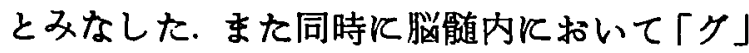
酸及びクルタミンの合成が行われていること る報告している. 中教授 ${ }^{26)}$ 子脳組織呼吸と 「ク」酸 $\mathrm{Na}$ ，及びアンモニアとの間に密接な

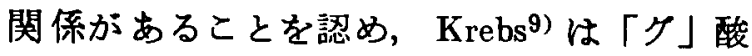
が脳切片についてKイオンの維持又は恢復に 関係をすつといい，岡本10)は「ク」酸がア女 チルコリンの生成を促進するのではないかと 報告している。

つぎに痦卛機序と「ク」酸の関係も密接な ものがあるとされ，林教授(1)等は「ク」酸 $\mathrm{Na}$ を皮質運動領野その他特定の部位飞注入， 鋈布すると，局在的な刺戟效果として間代性 痤攣が起ることを発見し，岡本 ${ }^{12}$ ，須田 ${ }^{13}$, 内山 ${ }^{13)}$, 石塚 ${ }^{14}$ 等がこの噔攣機序関して詳 細な報告を括こなつている。また Haber \& Saidel ${ }^{15)}$ ，和田 ${ }^{16)}$ 等により㽷彎時に打ける 「ク」酸を中心とする游離アミノ窒素量の减

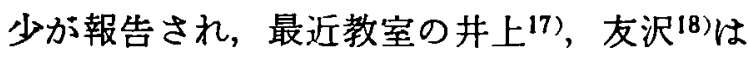
痤摮家兔脳髄に同様の減少をみると発表して

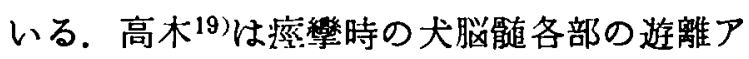
ミノ窒素を測定しレンズ㤥に打ける著明な減 少を観察報告している。 また井上 ${ }^{17}$ は潜在性 脳局「ア」家象脳艏飞括ける遊離アミノ窒素 量は正常群飞比して減少の傾向を示しており， 痙敩誘発時とくに著明であることを認めてい る。また清水 ${ }^{26)}$ は術萄糖附加灌流垁騟法によ り脳剧「ア」家鬼脳骮道飞括いては糖の消費が 抑制されることを認め，さらに宇都宮20)はこ れに「ク」酸を附加することで正常に戻るこ とより脳屖「ア」家鬼脳䯣では「ク」酸が不 足しているのではないかといつている.

このようK「グ」酸を中心とする脳榷アミ ノ酸が脳新陳代謝及び痙攣機序と密接な関係 があるとみなされるのであるが，私は前編に おいて生成した慢性脸局「ア」家兔脳韨につ いて遊離アミノ窒素量を測定しこの痤攣準 備状態を附与された脳而道の新陳代謝がどのよ うな変動を生じているかを知るうとして本研 究を企てた次第である。

\section{第 2 章 実験材料並に実鏂方法}

第 1 節 実験動物

a) 正常家霓は前編，第 2 章，第 1 節飞用 いたと同様の $2 \mathrm{~kg}$ 前後白色成熟家鬼を使用し た.

b）牛脳灰「木」加牛血清群（以下 $\mathrm{P}$ 群と 略記する) は，前編，第 2 章，第 2 節，第 3 節及び第 4 節にのべた方法にて，牛脳灰「木」 加牛血清の 4 倍稀釈液を家兔耳静脈より 6 ケ 月間反覆注入したのち，1ケ月間及び 3 ケ月 間無処置飞放置したもの（以下各々 $\mathrm{P}_{1}$ 群， $\mathrm{P}_{3}$ 群と略記する）を実験材料として使用した。

c） $\alpha$ 連菌群(以下 A 群と略記する)は，前 編，第 2 章，第 2 節及び第 4 節飞述べた方法 にて, 家鬼副鼻胵内に生菌 $10 \mathrm{mg}$ 宛 6 ケ月間 反覆注入したのち，4 ケ月及び 8 ケ月間無処 置に放置したもの（以下各々 $\mathrm{A}_{4}$ 群, $\mathrm{A}_{8}$ 群と 略記する）を実験材料として使用した。

第 2 節 抽出液作製法

脳の採取は, 両側頸動脈より失血致死せし め, 直ちに開脳し脳を一塊として剔出した。 剔出脳は丁寧飞硬脳膜及び凝血を除去し，一 側大脳半球をとり秤量したのち蓋付瓶中に入 れ硫酸々性純アルコール 10cc を添加し，72 時間氷室内に保存した. 本操作は後述の脱脂 页び除蛋白を容易にするためである．72時間 後に抵中より取出し, 滤紙にて純アルコール を払拭し，乳鉢内にて倍量の石油エーテル（沸 点 $40^{\circ} \mathrm{C}$ 以下) と混和して充分飞磨砕する. 磨砕 後石油エーテルを注加して蓋付瓶内に入れ室 温飞放置し, 24 時間後飞 3000 回転, 15 分間遠 沈を抽こない, 石油エーテルを更新した.この 操作を 3 回反㙏して脱脂を終り，ついで10倍

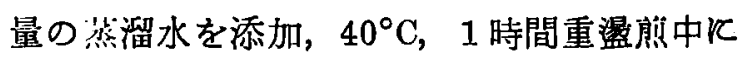
て穓拌しつつ抽出を行つた。 この抽出液を無 夾潓紙にて㵂過し，液量を測定して抬いた。

この滤液 $5 \mathrm{cc}$ 飞 $0.6 \% \quad \mathrm{KH}_{2} \mathrm{PO}_{4} 5 \mathrm{cc}, 10 \%$ Squibb 氏尿素分解醉素溶液 $0.1 \mathrm{cc}$ を加兑, 瞬卵器内飞30分間放置した。 この操作により 湑液中の尿素は分解される.

ついで Folin-Wu 氏変法にて除蛋白を行っ 
た。 すなわち $1 / 12 \mathrm{~N}$ 硫酸 $16 \mathrm{cc}$ 飞抽出液 2cc を加克, $10 \mathrm{~g} / \mathrm{dl}$ タングステン酸ソーダ溶液

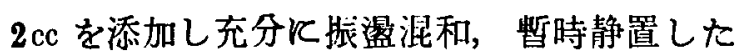
のち無灰瀂紙にて湑過した。この滤液を硬質 コルヘンン採り，水酸化マグネンウム浮遊液 数滴を商下，5１0 分間省沸し容積を半減せ しめた。 ついで氷醋酸を滴下し，液が酸性と なり水酸化マクネンウムが溶解するにいたら しめる. 硬質コルヘンンは蒸溜水少量にて洗い, 初めの容積となるようにした。遊離アミj窒 素の定量には，この液 $5 \mathrm{cc}$ を使用した。

盲験飞は $10 \%$ Squibb 氏艮祈分解醉素溶液 $1 \mathrm{cc} k 10 \mathrm{~g} / \mathrm{dl}$ タングステン酸ソータ溶液 $0.5 \mathrm{cc}$ 及び $1 / 12 \mathrm{~N}$ 硫酸 $4 \mathrm{cc}$ を加え，10cc とな

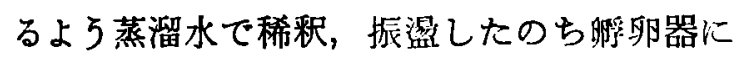
30分間放置した。これを無灰滤紙にて滤過し， 滤液 $1 \mathrm{cc}$ を $100 \mathrm{cc}$ となるよう稀釈した。この 液 5ccをすちいて盲験を行つた。

第了節 遊隻アミノ咥素定量法

定量はVan-Slyke $\mathrm{e}^{21)}$ のガス顺压法により 行つた. すなおち滕讲22), 赤堀23), 滕田の記 載化もとずき，Vin.Slyke \& Neil の装置を 用い，抽出宁は 50cc のものを使朋した。 試楽としては

1）亜硝酸ソータ液は 1 l の水に $\mathrm{NaNO}_{2}$ $800 \mathrm{~g}$ を加温溶解せしめた。

2）水醌酸

3）アルカリ性過マンガン酸カリ液は，1l の $10 \% \mathrm{NaOH}$ 飞 $50 \mathrm{~g}$ の $\mathrm{KMnO}_{4}$ を飽和せ しめた。この液は毎回新作製し, 使用前室 温飞放置して空気を飽和せしめた。

4）カプリールアルコールを用意した.

測定には，聴液 5cc を抽出室に入れ，氷醁 酸 Icc を数回飞洗込み，カプリールアルコー ル1滴を加えて泡沫の発生を防いた。. 抽出室 を真空として 1 分間200 300回前後の速度に て 2 分間振温し，その際抽出された空気を排

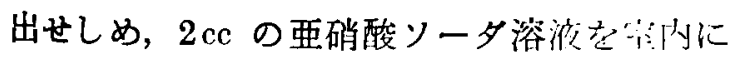

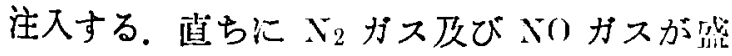
飞発生する. 水銀面を抽出室の $50 \mathrm{ec}$ 目盛附近 にまで下げ，この時の反応温度に応じて所定 の時間を放置し，最後の 1 分間はガスの発生
を完全とするために 200〜 300 回前後の速度 で振曒した。 この洔発生したカスを Hempelpipette 内に移行せしぬ, pipette 内のアルカ

・リ性過マンガン酸カリ液と混和せしめて NO ガスを吸收， $\mathrm{N}_{2}$ ガスのみを再び抽出室内に 返した。水銀面を所定の標線までさげて $\mathrm{N}_{2}$ ガスの压を測定し，計算により脳髄新鮮重量 $1 \mathrm{~g}$ 中の遊離アミノ咥素量 $(\mathrm{mg})$ 飞换算した.

また同封に全く同様の操作をもつて盲験を 括こない，亜硝酸ソーダ溶液及び尿素分解醇 素溶液により生ずる誤差を求めて補正を抗こ なつた.

な笑験に先立ち、クリンン $0.1 \mathrm{~g}$ を $50 \mathrm{cc}$

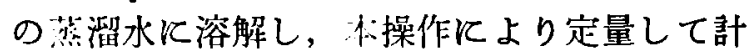
算値 $(0.7466 \mathrm{mg})$ と一致することを碓めた.

\section{第3章 実験成嚗}

第 1 節 正常家兔群

正常家息15匹飞括ける脳髄遊離アミノ室素 量を, 新鮮脸重量 $1 \mathrm{~g}$ 換算値にて示せば平均 $0.4161 \mathrm{mg}$ ，棐準偏差 \pm 0.0444 である。これ

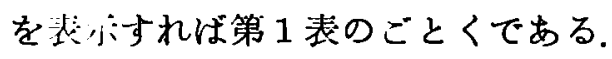

\begin{tabular}{|c|c|}
\hline & $\begin{array}{l}\text { アミノ } \\
\text { 窒菜量 }\end{array}$ \\
\hline 1 & 0.3608 \\
\hline 2 & 0.5362 \\
\hline 3 & 0.4103 \\
\hline 4 & 0.4356 \\
\hline 5 & 0.3421 \\
\hline 6 & 0.3315 \\
\hline 7 & 0.3816 \\
\hline 8 & 0.5015 \\
\hline 9 & 0.4298 \\
\hline 10 & 0.3991 \\
\hline 11 & 0.4026 \\
\hline 12 & 0.4261 \\
\hline 13 & 0.4262 \\
\hline 14 & 0.4084 \\
\hline 15 & 0.4501 \\
\hline 平 & 0.4161 \\
\hline 標凖偏差 & \pm 0.0444 \\
\hline
\end{tabular}

第 1 表 正常群
第 2 表 $\mathrm{P}$ 群。

\begin{tabular}{|c|c|c|}
\hline & & 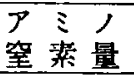 \\
\hline 1 & \multirow{7}{*}{$\mathrm{P}_{3}$ 群 } & 0.3265 \\
\hline 2 & & 0.2756 \\
\hline 3 & & 0.2827 \\
\hline 4 & & 0.3132 \\
\hline 5 & & 0.3820 \\
\hline 6 & & 0.2784 \\
\hline 7 & & 0.3231 \\
\hline 8 & \multirow{8}{*}{$\mathrm{P}_{1}$ 群 } & 0.2812 \\
\hline 9 & & 0.3056 \\
\hline 10 & & 0.2057 \\
\hline 11 & & 0.3726 \\
\hline 12 & & 0.3266 \\
\hline 13 & & 0.3419 \\
\hline 14 & & 0.3781 \\
\hline 15 & & 0.3101 \\
\hline 䧑 & 均 & 0.3135 \\
\hline & & \pm 0.0352 \\
\hline
\end{tabular}

第 2節 $\mathrm{P}$ 群 $\mathrm{P}$ 群（ $\mathrm{P}_{1}$ 群 8 匹， $\mathrm{P}_{3}$ 群 7 匹） 15 匹に招け 


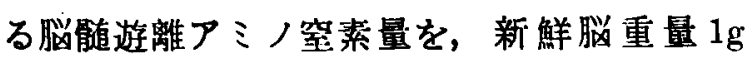
換算值にて示せぼ平均 $0.3135 \mathrm{mg}$, 標準偏差 士0.0352である．これを表図示すれば第 2 表,

第 3 表 A 群

\begin{tabular}{|c|c|c|}
\hline & & 勇至 \\
\hline 1 & \multirow{7}{*}{$\mathrm{A}_{8}$ 群 } & 0.2774 \\
\hline 2 & & 0.3265 \\
\hline 3 & & 0.2040 \\
\hline 4 & & 0.3608 \\
\hline 5 & & 0.2860 \\
\hline 6 & & 0.2850 \\
\hline 7 & & 0.2056 \\
\hline 8 & \multirow{8}{*}{$\mathbf{A}_{4}$ 群 } & 0.3210 \\
\hline 9 & & 0.3021 \\
\hline 10 & & 0.2980 \\
\hline 11 & & 0.2907 \\
\hline 12 & & 0.2502 \\
\hline 13 & & 0.3718 \\
\hline 14 & & 0.3450 \\
\hline 15 & & 0.3311 \\
\hline 平 & 均 & 0.2970 \\
\hline 標身 & & \pm 0.0480 \\
\hline
\end{tabular}

第 1 図のごとくであ る.

\section{第 3 節 $\mathrm{A}$ 群} $\mathrm{A}$ 群 (A4 群 8 匹， $\mathrm{A}_{8}$ 群 7 匹) 15 匹に 招ける脳髄遊離ア ミノ窒素量を，新 鮮脳重量 $1 \mathrm{~g}$ 換算値 にて示せば, 平均 $0.2970 \mathrm{mg}$, 標準偏差

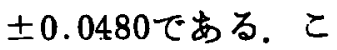
れを表図示すれば第 3 表, 第 1 図のごと くである.

\section{第 4 節 小括}

1）正常家鬼脳䯣 に打ける遊離アミノ 窒素量は $0.4161 \mathrm{mg}$ であつて，この成績

第1図遊離アミノ咥素量

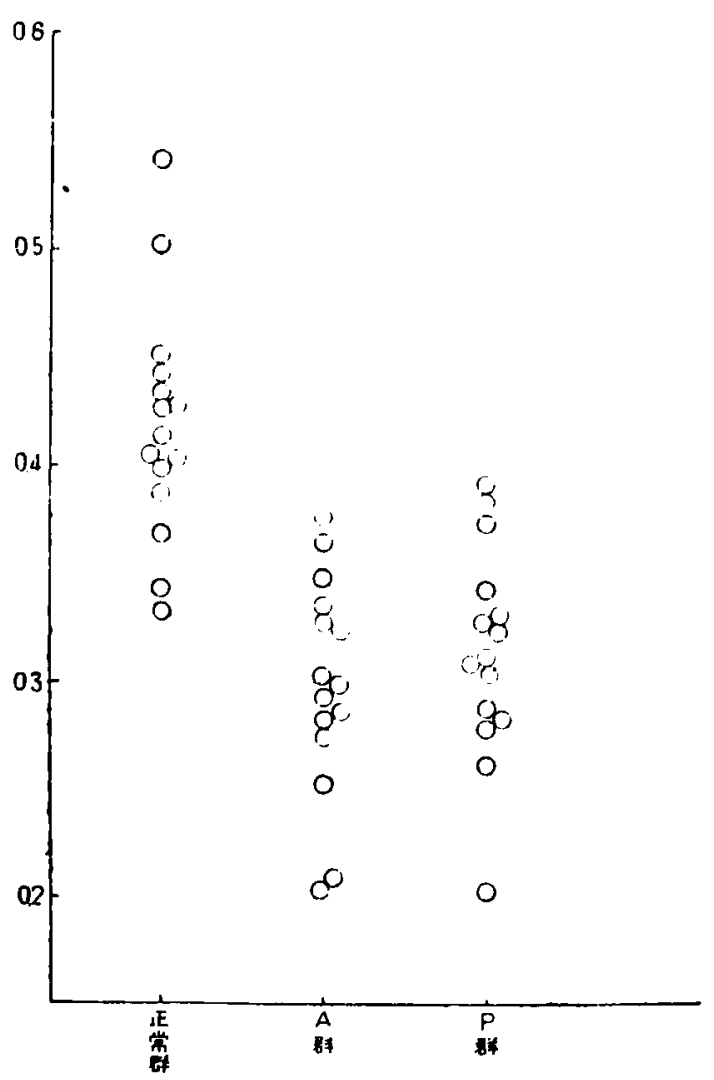

は井上，友沢の成樍と一致している.

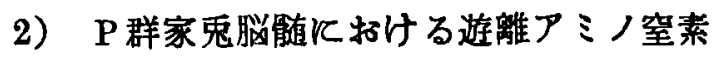
量は $0.3135 \mathrm{mg} て ゙$, 正常群飞比して $25 \% 6 の$ 減少を示している.

3） A 群家鬼脳艏に招ける遊離アミ／窒素 量は $0.2970 \mathrm{mg}$ で, 正常群比比して29\%の減 少を示している.

4）上述の成績を $\mathrm{P}$ 群は $\mathrm{P}_{1}$ 群， $\mathrm{P}_{3}$ 群， $\mathrm{A}$ 群は $\mathrm{A}_{4}$ 群， $\mathrm{A}_{8}$ 群と無処置期間別に図示する と第 2 図のごとくであつて, 効果注射終了後 の放置期間が長期となつても遊離アミノ窒素 量の减少は増加してきていないことがわか る。

第 2 図遊離アミノ窒素量 (無処置期間別)

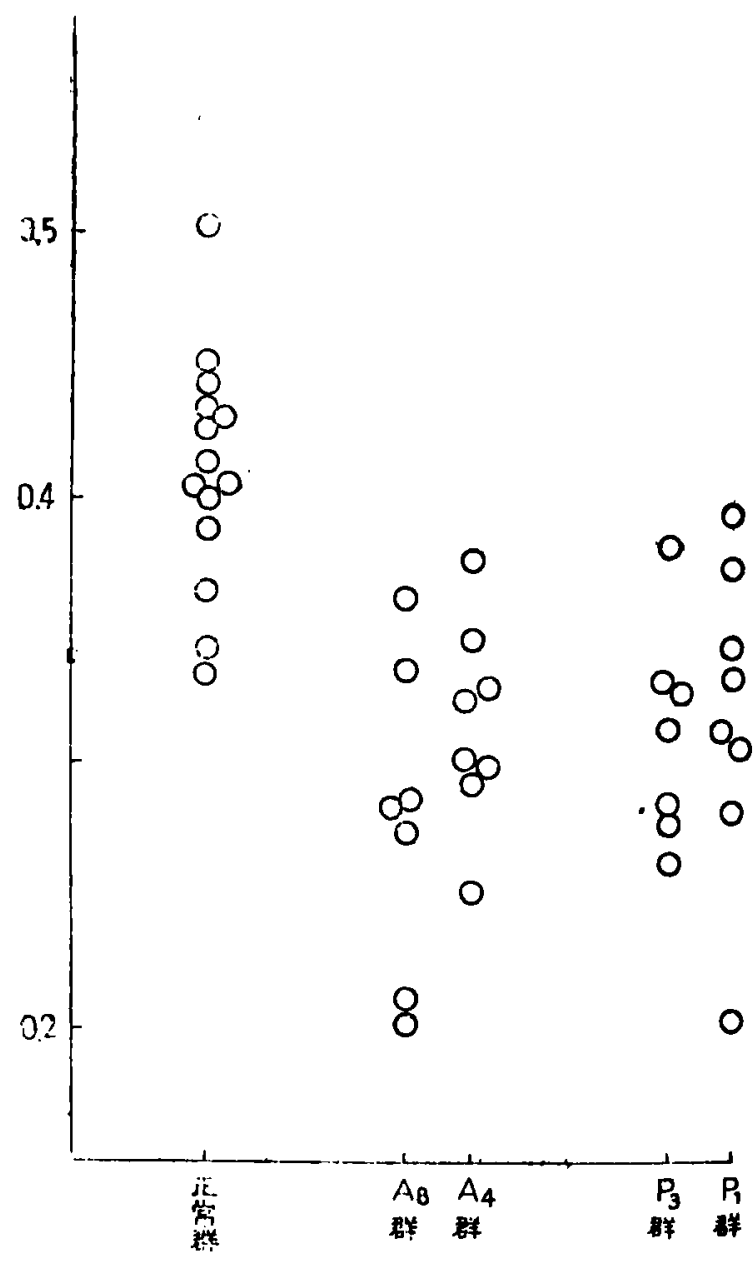

第 4 章 総括並に考按

私は前編飞述べたごとく，牛脳灰「木」加 牛血清の 4 倍稀彩液を家鬼耳静脈内《注入す る方法, $\boldsymbol{\alpha}$ 連菌を副鼻腔内注入して頭蓋内に 
逆行せしめる方法とをるちいて，比較的自然 飞近く，かつごく軽い抗原抗体反心を長期間 反覆せしめ，痤攣誘発をおこなわないで，乙 かる長期間の無処置期間を放置した慢性脳局 「ア」家鬼を生成した。しかしてこの慢性脳 局「ア」家兔脳盏各部について, Acetylcholin 分解醉素 Cholinesterase (以下 $\mathrm{ChE}$ と略記す る）活性值を測定し特異な神経組織の過敏状 態を生じていることをしり，実験的痙擎準備 状態が附与されていると推論したのであるが, 私はさらにこのよろな家兔脳艏の遊離アミノ 窒素量を測定比較することにより，脳新陳代 謝がどのような変動を生じているかを知りた いと考えて本実験を企てた。

私の実験では，慢性脳局「ア」家鬼群の脳 骾遊離アミノ室素量が P 群， $\mathrm{A}$ 群共江正常群 飞比して25\%，29\%と明らかに減少を示して いる. またこの減少の傾向は, 效果注射終了 後の無処置期間が長期となつても増加してと ないことより，比較的永続性のある変化であ ると考只られる。をた抗原の種類及び感作方 法の異つた P 群, A 群の成績がさしたる差を 認めないことから，このよ5な変動は脳局 「ア」状態炕つて生じたるのであると考え られるのである.

すでにのべたごとく，脳哊全遊離アミノ空 素量の過半数は「グ酸であり, 脳䯣内に括 ける特異的な「グ酸の作用機序により，遊 離アミノ窒素の変動は主として「グ」酸を中 心としたものであると考号れるのである.

すなわち $\mathrm{Krebs}^{9)}$, Weil-Malherbe ${ }^{8)}$ ，中26)等 により，脳内「ク」酸が脳内代謝過程におい て特異にしてかつ非常に重要な役割をしめて いることが報告されている .最近「グ」酸の 各種脳内反応機序は, 相互飞関係しあつて統 一された代謝の流れを作つていると考えられ ており，主な作用としては脳機能と直結する $\mathrm{NH}_{3}$ を固定する作用, 脳組織内のKを一定量 て維持し，これと密接な関係があるとされる 嫌気性解糖の抑制, 好気性解糖の促進作用か あり，さらK Ach 合成を促進する作用があ ると考えられている.すなわち「ク」酸を中
心とする脳髄遊離アミノ窒素の変動は, 畄内 に拈ける各種代謝の異常を表わするのであり， 同時に各種代謝飞異常を惹起せしめるすので もあると考えられる.このことは脳における 最も著明な異常代謝を代表する症尛時の脳内 「グ酸の変動と，「ク」酸による痤樂誘発に 関する多くの報告によつてもしることができ る. すなわち Haber \&. Saidel ${ }^{15)}$, 和田16)等 は痤戀時に「ク」酸を中心とする脸髄遊離ア ミノ咥菜が著明に減少することを報告し，岡 本 ${ }^{24}$ は皮質に打いて座繁による「ク」酸の変 動を認め，この変動が㽷攣を起す原因により 異なることを確めている。教室の井上 ${ }^{17)}$, 友 沢 ${ }^{18)}$ も家息脳髄の遊離アミノ窒素量及び「ク」 酸が痙卛誘発時に著明な減少を示すことを認 め, 高木 ${ }^{(9)}$ は犬胹髅各部の遊離アミノ窒素量 の変動を瘵㘘各期について測定し，とくにレ ンズ核に括ける減少が著しいと報告している。 また林教授 25$)$ 及びその門下(2)13)14)は「ク」酸 Naを注入或は䇾布することとより，脳の部 佁により特定な理動現象及び自律神経系の变 化を起さすことが出来ると発表している.

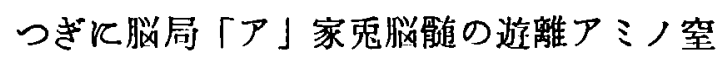
素に関しては, 教室の井上 ${ }^{17}$ が減少を認め, 宇都宮 ${ }^{20)}$ は灌流䒠驞で「ク」酸附加により糖 代謝が正常化することから脳内「ケ」酸の减 少を推諭している.

私の寒験飞招いても慢性脳局「ア」家兔脳 髄に遊離アミノ窒素量の減少を認めたのであ るか，痙樂誘発による後天的変化を除外して あることより考えて，この減少は痙攣発作時 に招ける異常代謝とは別個のすのと考觉るへ きであろう。すなわち病攣発作時にみられる ような比較的一過性の代謝変動ではなく，も つとその脳骾に固定した異常代謝によるもの と括もわれ，このことは無処置期間が長期と なつてる斿離アミノ窒素量の減少が正常飞復 してこない成績からも考学られるところであ る.こっでさきにのべた慢性脳局「ア」家兔

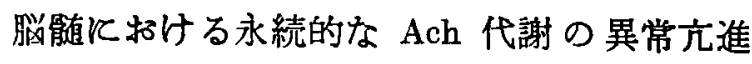
と考えあわせてみると，この「ケ」酸を中心 とする遊離アミノ窒素の変動が, 媛變準備状 
態を附与された特異な脳内代謝過程の一つの あらわれであろうと解釈されうるのである。 またこのよ5な慢性脳局「ア」の成績が抗原 の種類及び感作方法が異なつても差異を認め えない点より，上述の脳内異常代謝は慢性脳 局「ア」状態によつて生じたものと考えられ る.

私は 2 種の方法をるつて長期飞抗原抗体反

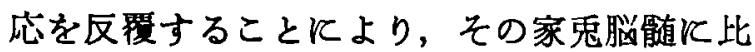
較的永秸性のある遊離アミノ咥素量の減少を 認めたのであるが，これはアレルギー成因に よる痤攣隼備状態附与炕因するすのであると 考える次第である。

\section{第 5 章 結 論}

牛脸灰「木」加牛血清の 4 倍稀䣋液を静脈 内飞注入する方法と， $\alpha$ 連菌を副鼻腔内に注 入する方法とを用いて 6 ケ月間抗原抗体反応 を反榎したのち，1ケ月間以上 8 ケ月間の無

\section{文}

1）中 修三：精神々経誌，49；87 (1945)

2) Elliot \& Penfield : J. of Neurophysiol., 11 ; 485 (1948)

3) Mc Quarry : American J. of Dis. of Child., $38 ; 451$ (1929)

4) Shimizu : Biochem. Zeit., 117 ; 252 (1921)

5) Krebs, Eggleston \& Hens : Biochem. J., 44 ; 159 (1949)

6) Weil-Malherbe : Bioch, J., 30 ; (1936)

7) Hamilton : J. Biol. Chem., 158 ; 397, (1945)

8) Weil-Malherbe : Metabolism \& Funktion in Nervous Tissue, Biochemical Socity Symposia., No. 8 ；23 (1952) (岡本彰喏 : 神経化学, 263 (1954) より引用)

9) Krebs : Biochem. J., 33 ; 551 (1939)

10) 岡本歌子, 岡本彰祐 : 神経化学, 294 (1954) 上 り引用

11）林嗃：条件反射， $4 ； 181$ (1942)
処置期間を括いた慢性脳局「ア」家鬼を生成 し，脳髄遊離アミノ窒素量を測定しつぎの所 見をえた。

1）慢性脳局「ア」家鬼脳髄の遊離アミノ 室素量は正常家鬼に比して著明の減少を認め た.

2）抗原の種類及び感作方法による差異は 殆ど認められなかつた。

3）効果注射終了後の無処置期間が長期と なつても, 脳艏遊離アミノ窒素量の減少は変 動を見なかつた。

4）非常飞弱い抗原抗体反応を長期間反覆 することにより，家象絾髄に抢ける遊離アミ , 窒素量は比較的永続性と考えられる減少を 示し，これは笑験的痤卛準備状態附与による 脳内代謝異常飞因するすのと考えられる。

擱筆するにあたり，終始御愁篤なる御指導と御校 閲を賜つた恩師陣内敉授に深甚なる謝意を捧ける。

献

12) 岡本彰祐：日本生理誌, 13 ；555 (1951)

13）須田勇, 内山寿照子，阿部歌子，水野節子：条 件反射，11 12；49(1944)

14) 石琭保：条件反射, 6 ； 47 (1943)

15) Haber \& Saidel Federat. Proceed., 7 ; 1 (1948)

16) 和田 漳：精神々経誌，53；20（1951）

17）井上圭爾：岡山医学会雑誌，64；1646 (1952)

18）友沢久雄：第14回日本脳神経外科学会飞発表

19）高木秀雄：岡山医学会雑誌，65；1113 (1953)

20）宇都宮信博：岡山医学会雑誌，65；1345(1953)

21) Van-Slyke : J. Biol. Chem., 16 ; 231 (1913)

22) 藤井暢三：生化学実験法（定量箱），73 (1947)

23）赤珮四郎：アミノ酸及び蛋白罂, 176 (1946)

24）岡本彰祐：生体の科学, 5；46 (1953)

25）中 詣三：生体の科学, 4; 3, 10 (1935)

26）清水隼也：岡山医学会雑誌，65；43 (1953) 
Dept. of Surgery, Okayama University Medical School

(Director : Prof. Dr. D. Jinnai)

On the Cholinesterase activity, free aminonitrogen and

ketoenolic granuli in nerve cells in chronic cerebral local anaphylactic rabbits.

Part II. On free aminonitrogen in rabbits brain with chronic cerebral local anaphylaxis (CCLA)

$B y$

\section{Tetsuro HATAYAMA}

The free aminonitrogen in the brain with CCLA was strikingly decreased in comparison with that of the normal, and no difference was observed between the kinds of antigen or the methods of sensitization.

The decrease of free aminonitrogen was not influenced by protraction of the period without procedures after the last anaphylactic reactions, and the decrease was seen to be longstanding, when these very slight anaphylactic reactions were repeated for a long time. This is considered to be due to the abnormal brain metabolism in the state of an experimental epileptic arrangement. 